\title{
p,p'-DDE Induces Apoptosis of Rat Sertoli Cells via a FasL-Dependent Pathway
}

\author{
Yuqin Shi, Yang Song, Yinan Wang, Xianmin Liang, Yafei Hu, Xia Guan, \\ Jin Cheng, and Kedi Yang
}

MOE Key Lab of Environment and Health, Department of Occupational and Environmental Health, School of Public Health, Tongji Medical College, Huazhong University of Science and Technology, Wuhan, Hubei 430030, China

Correspondence should be addressed to Kedi Yang, yangkd@mails.tjmu.edu.cn

Received 28 February 2009; Accepted 20 May 2009

Recommended by M. Firoze Khan

\begin{abstract}
One,1-dichloro-2,2 bis(p-chlorophenyl) ethylene (p,p'-DDE), the major metabolite of 2,2-bis(4-Chlorophenyl)-1,1,1trichloroethane (DDT), is a known persistent organic pollutant and male reproductive toxicant. It has antiandrogenic effect. However, the mechanism by which $\mathrm{p}, \mathrm{p}^{\prime}$-DDE exposure causes male reproductive toxicity remains unknown. In the present study, rat Sertoli cells were used to investigate the molecular mechanism involved in p, $\mathrm{p}^{\prime}$-DDE-induced toxicity in male reproductive system. The results indicated that $\mathrm{p}, \mathrm{p}^{\prime}$-DDE exposure at over $30 \mu \mathrm{M}$ showed the induction of apoptotic cell death. p, $\mathrm{p}^{\prime}$-DDE could induce increases in FasL mRNA and protein, which could be blocked by an antioxidant agent, N-acetyl-l-cysteine (NAC). In addition, caspase- 3 and -8 were activated by $\mathrm{p}, \mathrm{p}^{\prime}$-DDE treatment in these cells. The activation of NF- $\kappa \mathrm{B}$ was enhanced with the increase of $\mathrm{p}, \mathrm{p}^{\prime}$-DDE dose. Taken together, these results suggested that exposure to $\mathrm{p}, \mathrm{p}^{\prime}$-DDE might induce apoptosis of rat Sertoli cells through a FasL-dependent pathway.
\end{abstract}

Copyright (C) 2009 Yuqin Shi et al. This is an open access article distributed under the Creative Commons Attribution License, which permits unrestricted use, distribution, and reproduction in any medium, provided the original work is properly cited.

\section{Introduction}

Endocrine disrupting chemicals (EDCs) are a structurally diverse group of compounds that may adversely affect the health of humans, wildlife and fisheries, or their progenies, by interaction with the endocrine system [1]. It has been suggested that EDCs pose a potential risk and can alter the hormone balance in humans and wildlife [2]. These environmental xenobiotics may impair the normal embryonic development and disrupt normal reproductive functions in adulthood [3, 4]. Organochlorine pesticide, such as 2,2-bis(4-Chlorophenyl)-1,1,1-trichloroethane (DDT), is a widespread environmental xenobiotics. DDT is a persistent organic pollutant with the features of wide pollution, huge harm, and longtime persistence in environment, and entering the living system via biomagnification of food chain. It may persist mainly by the forms of metabolite 1,1 -dichloro2,2 bis(p-chlorophenyl) ethylene ( $\mathrm{p}, \mathrm{p}^{\prime}$-DDE) in the blood lipid and adipose tissue for several decades [3,5-7]. Though having being banned or restricted for three decades, DDT is still being used for control of vectors in public health in some developing countries [8-10]. It has been reported that some abnormalities in sexual development in rats and wildlife might be associated with exposure to $\mathrm{p}, \mathrm{p}^{\prime}$-DDE [11, 12]. $\mathrm{p}, \mathrm{p}^{\prime}-\mathrm{DDE}$ is antiandrogenic and can inhibit androgen binding to the androgen receptor [11].

Cell death by apoptosis is a part of normal development and maintenance of homeostasis [13], but it is also involved in pathological situation associated with sterility. In the testis, apoptosis is such a common programmed event that $75 \%$ of germ cells are reduced by spontaneous apoptosis [14]. However, excessive or inadequate apoptosis of testicular cells will result in abnormal spermatogenesis or testicular tumors [15]. The Sertoli cell is the only somatic cell found in the testicular seminiferous tubule of mammalian. It plays major roles in the maintenance and control of spermatogenesis, such as structural support, participation in germ cell's movement and spermiation, nourishing germ cells by secreting the tubular fluid and numerous factors $[16,17]$. Therefore, the supporting capacity of Sertoli cells in toto is a limiting 


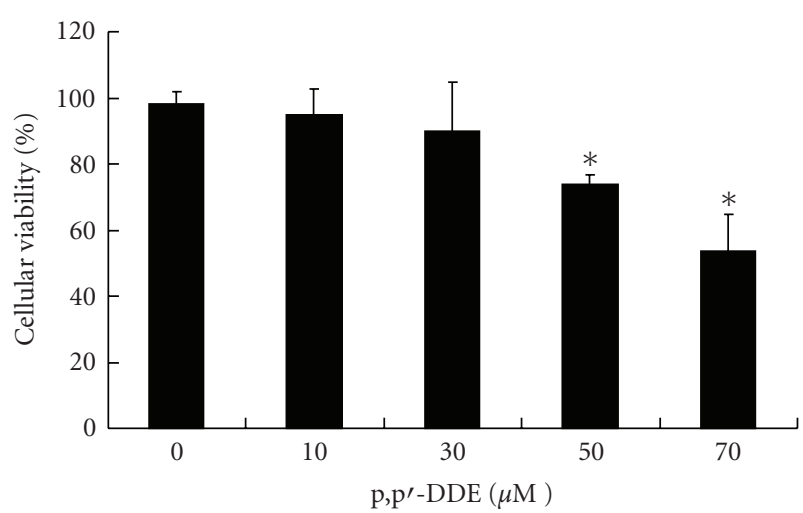

Figure 1: Effect of $\mathrm{p}, \mathrm{p}^{\prime}-\mathrm{DDE}$ on the viability of rat Sertoli cells with MTT assay. MTT (3-(4, 5-dimethylthiazol-2-yl)-2, 5diphenyltetrazolium bromide) can be reduced by the mitochondrial dehydrogenase of viable cells to blue formazan product which can be measured spectrophotometrically. Cells were treated with $0.3 \%$ DMSO, $10,30,50$ or $70 \mu \mathrm{M}$ p, $\mathrm{p}^{\prime}$-DDE for 24 hours, and the optical density (OD) was measured by MTT. Cellular viability $(\%)$ was calculated using the following equation: cellular viability $(\%)=\left(\mathrm{OD}_{\text {treatment }} / \mathrm{OD}_{\text {control }}\right) \times 100$. Significant difference is $\left(^{*}\right) P<$ .05 , compared with the control group.

factor controlling germ cell's proliferation and output [18]. Since the number of Sertoli cells can only determine a finite number of spermatozoa in the seminiferous tubules [19], any agent that impairs the viability of Sertoli cells may cause serious effect on spermatogenesis. Though there have been some reports concerning $\mathrm{p}, \mathrm{p}^{\prime}$-DDE-induced toxicity in male reproductive system $[20,21]$, few studies investigated Sertoli cells. We have previously examined the effects of $\mathrm{p}, \mathrm{p}^{\prime}$-DDE on Sertoli cells [22]. That study demonstrated that p, $\mathrm{p}^{\prime}$-DDE could affect the expression of several functional marker genes including transferrin (Tf) and androgen-binding protein $(\mathrm{ABP})$. Besides, ROS generation might play a critical role in the initiation of $\mathrm{p}, \mathrm{p}^{\prime}$-DDE-induced apoptosis in rat Sertoli cells through mitochondria-mediated pathway [23]. The aim of the present study was to determine the effects of different concentrations of $\mathrm{p}, \mathrm{p}^{\prime}-\mathrm{DDE}$ on apoptosis of Sertoli cells and to investigate FasL-dependent apoptotic pathway. We investigated the expressions of FasL and activation of NF- $\kappa \mathrm{B}$ in $\mathrm{p}, \mathrm{p}^{\prime}$-DDE-induced apoptosis. As caspase family members play an important role in spermatogenesis and apoptosis, it is also of interest to determine the regulation of caspase- 3 and -8 in $\mathrm{p}, \mathrm{p}^{\prime}$-DDE induced apoptosis.

\section{Materials and Methods}

2.1. Animals. 18- to 20-day-old male Sprague-Dawley (SD) rats were purchased from Tongji Medical College Animal Laboratory (Wuhan, China) and acclimatized in accordance with the Guide for the Care and Use of Laboratory Animals published by the Ministry of Health of China.

2.2. Primary Culture of Sertoli Cells and Cell Treatment. Primary culture of Sertoli cells was prepared using sequential enzymatic procedures that had been previously described [24] with modifications. Briefly, testes from 18- to 20-dayold Sprague-Dawley rats (day of birth $=$ day 0 ) were collected, excised rapidly, decapsulated, cut into small fragments, and washed twice in Hanks' balanced salt solution (HBSS). The fragments were then digested sequentially in $10 \mathrm{~mL}$ of HBSS containing $0.25 \%$ trypsin (Amresco, Solon, OH, USA) and $0.1 \%$ collagenase (type I, Invitrogen, Grand Island, NY, USA) in a shaking water bath $\left(35^{\circ} \mathrm{C}, 120\right.$ cycles $\left./ \mathrm{min}\right)$ for 30 minutes. Digested cells suspension was washed extensively with no-phenol red-Dulbecco's modified Eagle's medium (DMEM, Invitrogen, Grand Island, NY, USA) to remove peritubular cells, followed by filtration through B-D Falcon cell strainers (nylon mesh size, $70 \mu \mathrm{m}$ ). The final Sertoli cells suspension was supplemented with $5 \%$ fetal bovine serum (Invitrogen, Grand Island, NY, USA) and seeded in cultured bottle in a humidified atmosphere of $95 \%$ air $-5 \% \quad \mathrm{CO}_{2}$ at $35^{\circ} \mathrm{C}$.

After 24 hours, these cells were extensively washed twice with HBSS solution to remove unattached cells, then treated with $20 \mathrm{mM}$ pH 7.4 Tris- $\mathrm{HCl}$ for 5 minutes and with serum starvation for 24 hours. The medium was renewed at a 2-day interval.

p,p'-DDE (DR Co., Augsburg, Germany) was dissolved in dimethylsulfoxide (DMSO, Sigma-Aldrich, St. Louis, MO, USA) as stock solution and diluted with culture medium to different concentrations before being added to the cells in culture. The final DMSO concentration in the medium was not more than $0.3 \%(\mathrm{v} / \mathrm{v})$, which did not affect the viability of Sertoli cells. Cells were cultured with $0.3 \%$ DMSO in the control group.

2.3. MTT Assay. This assay is dependent on the cellular reduction of MTT (3-(4, 5-dimethylthiazol-2-yl)-2, 5diphenyltetrazolium bromide) by the mitochondrial dehydrogenase of viable cells to a blue formazan product which can be measured spectrophotometrically. MTT (SigmaAldrich, St. Louis, MO, USA) was added into each well with the final concentration of $5 \mathrm{mg} / \mathrm{mL}$ for 4 hours. Thereafter, $200 \mu \mathrm{L}$ DMSO was added to dissolve the MTT formazan crystal. Then the culture plate was shaken for 10 minutes. The optical density (OD) of each well was measured at $490 \mathrm{~nm}$ with an ELISA Reader (Bio-Rad instrument Group, Hercules, CA, USA). Cellular viability (\%) was calculated using the following equation: cellular viability (\%) $=\left(\mathrm{OD}_{\text {treatment }} / \mathrm{OD}_{\text {control }}\right) \times 100$.

2.4. Apoptosis Assay with the Methods of AO/EB Double Staining and Flow Cytometric Analysis. AO/EB double staining: four $\mu \mathrm{L}$ of AO/EB (AO: $0.5 \mathrm{mg} / \mathrm{mL}$, Amresco, USA; EB: $0.5 \mathrm{mg} / \mathrm{mL}$ in PBS, Sigma, USA) dye mixture was mixed with $100 \mu \mathrm{L}$ treated and untreated cells of $1 \times 10^{6}$ cells $/ \mathrm{mL}$, and then $10 \mu \mathrm{L}$ of cells were added onto the glass slides to test by fluorescence microscopy (Olympus, Japan) using epiillumination and a filter combination suitable for observing fluorescein immediately with a magnification of $\times 40$.

Flow cytometric analysis: sertoli cells were seeded in a 6-well plate, and apoptosis was tested by apoptosis 


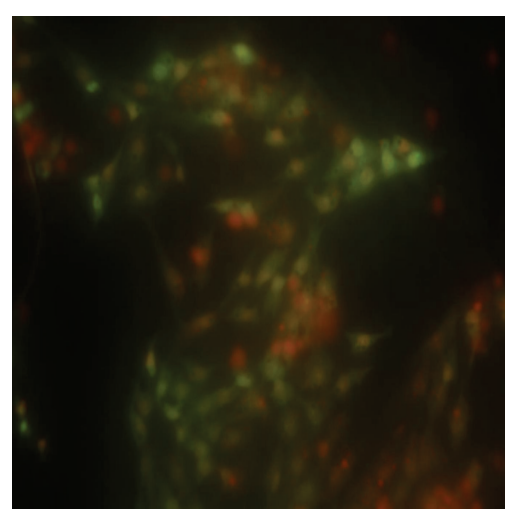

(a) Control

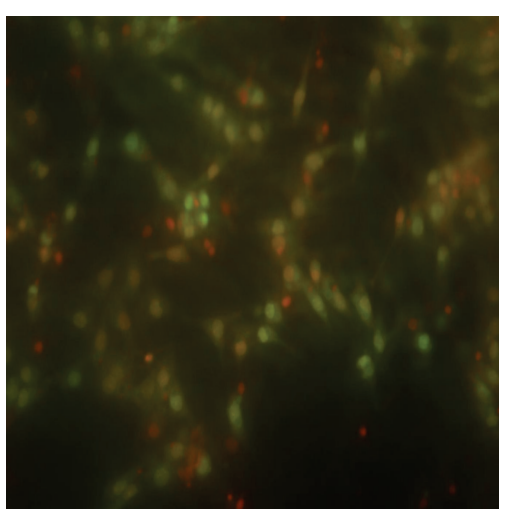

(b) $\mathrm{p}, \mathrm{p}^{\prime}-\mathrm{DDE} 10 \mu \mathrm{M}$

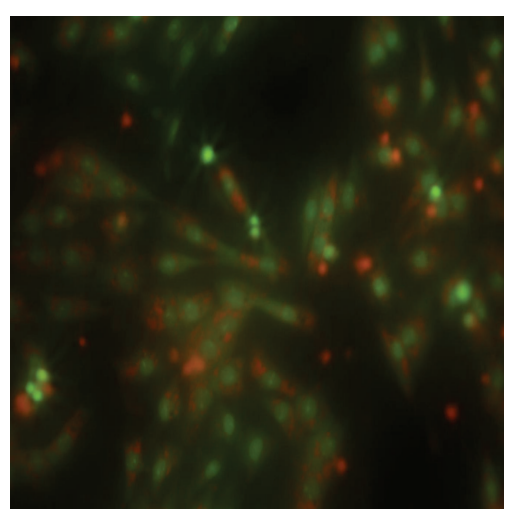

(c) $\mathrm{p}, \mathrm{p}^{\prime}-\mathrm{DDE} 30 \mu \mathrm{M}$

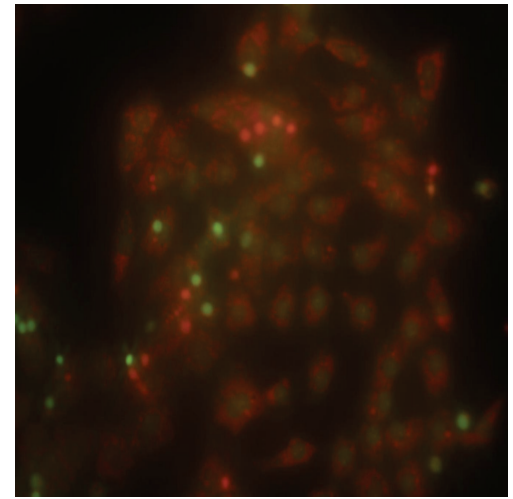

(d) $\mathrm{p}, \mathrm{p}^{\prime}-\mathrm{DDE} 50 \mu \mathrm{M}$

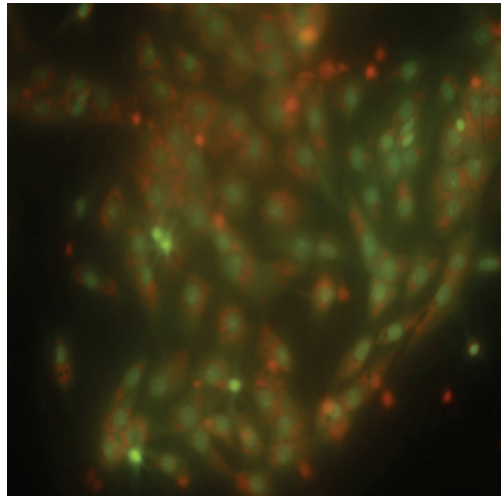

(e) $\mathrm{p}, \mathrm{p}^{\prime}-\mathrm{DDE}(50 \mu \mathrm{M})+\mathrm{NAC}(300 \mu \mathrm{M})$

FIGURE 2: Morphological observation of apoptotic effects of Sertoli cells treated with p, $\mathrm{p}^{\prime}$-DDE with or without NAC under a fluorescence microscope. Cells in control group (a) and cells treated with 10, 30, $50 \mu \mathrm{M}$ p, $\mathrm{p}^{\prime}$-DDE, and $50 \mu \mathrm{M}$ p, $\mathrm{p}^{\prime}$-DDE with NAC (b, c, d, and e) were observed by AO/EB staining. Original magnification is $\times 40$.

detection kit (Molecular probes, Eugene, OR) according to the instruction. In brief, the single Sertoli cell was collected and incubated in the buffer containing $1 \mu \mathrm{g} / \mathrm{mL}$ PI and $5 \mu \mathrm{L}$ Annexin $\mathrm{V}$ in the dark at room temperature for 15 minutes. Then the stained cells were analyzed by an FACS Calibur flow cytometer (Becton Dickinson, San Jose, CA, USA). The data were analyzed with Cellquest software (Becton Dickinson, San Jose, CA, USA).

\subsection{RT-PCR. The total RNA was extracted with Trizol} reagent (Life Technologies $\mathrm{GmbH}$, Karlsruhe, Germany) according to manufacturer's instructions. The medium of $100 \mathrm{~mL}$ culture bottle was discarded, $1.0 \mathrm{~mL}$ Trizol was added, and the contents were then placed in 1.5-mL EP tube without RNase. To isolate the samples, they were incubated at $0^{\circ} \mathrm{C}$ for 5 minutes. Then, $0.2 \mathrm{~mL}$ chloroform was added, and the tubes were shaken for 15 seconds and put on ice for 2-3 minutes, then they were centrifuged at $12000 \mathrm{rpm}$ for 15 minutes at $4^{\circ} \mathrm{C}$. The colorless upper aqueous phase containing the RNA was transferred to a new EP tube without RNase. An equal volume of isopropanol was added, and the RNA was precipitated by centrifugation. The RNA pellet was washed with 75\% ethanol and dissolved in water treated with diethylene pyrocarbonate $(10-20 \mu \mathrm{L})$. RNA purity was tested by eppendorf BioPhotometer (Eppendorf, Germany), showing an optical density ratio $\left(\mathrm{OD}_{260} / \mathrm{OD}_{280}\right)$ between 1.8 and 2.0. The RNA solution was conserved at $-70^{\circ} \mathrm{C}$ for further analysis.

Titanium one-step RT-PCR kit (Bdbiosciences Co., Beijing, China) was employed to amplify the FasL, caspase3 and -8 , and $\beta$-actin sequences. The master mixture included $5 \mu \mathrm{L} 10 \times$ one-step buffer, $1 \mu \mathrm{L} 50 \times$ dNTP mix, $0.5 \mu \mathrm{L}$ recombinant RNase inhibitor (40 units $/ \mu \mathrm{L}), 25 \mu \mathrm{L}$ thermostabilizing reagent, $10 \mu \mathrm{L}$ GC-Melt, $1 \mu \mathrm{L}$ oligo(dT) primer, and $1 \mu \mathrm{L} 50 \times$ RT-Titanium Taq enzyme mix. Following the addition of $1 \mu \mathrm{L}$ RNA sample, $2 \mu \mathrm{L}$ PCR primer mix, and $3.5 \mu \mathrm{L}$ RNase-free water into the reaction system, the final volume was $50 \mu \mathrm{L}$. PCR was performed with 30 cycles as follows: $50^{\circ} \mathrm{C}$ for 50 minutes (reverse transcription), $95^{\circ} \mathrm{C}$ for 15 minutes (to active Taq enzyme), $94^{\circ} \mathrm{C}$ for 30 seconds (denaturation), $53^{\circ} \mathrm{C}$ for 30 seconds (primer annealing), and $72^{\circ} \mathrm{C}$ for 1 minute (primer extension), and final extension for 10 minutes at $72^{\circ} \mathrm{C}$, with $4^{\circ} \mathrm{C}$ pause. After PCR, $2.5 \mu \mathrm{L}$ reaction mix was analyzed on $2 \%$ agarose gel with ethidium bromide $(0.5 \mathrm{mg} / \mathrm{mL})$. The levels of FasL and caspase- 3 and -8 expression were measured by densitometric analysis and standardized by comparison to the $\beta$-actin control using a digital imaging and analysis system (Biocapt MV software). 


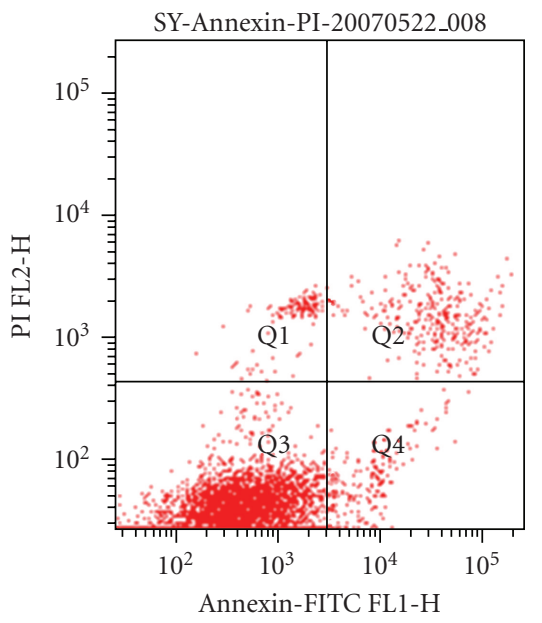

(a)

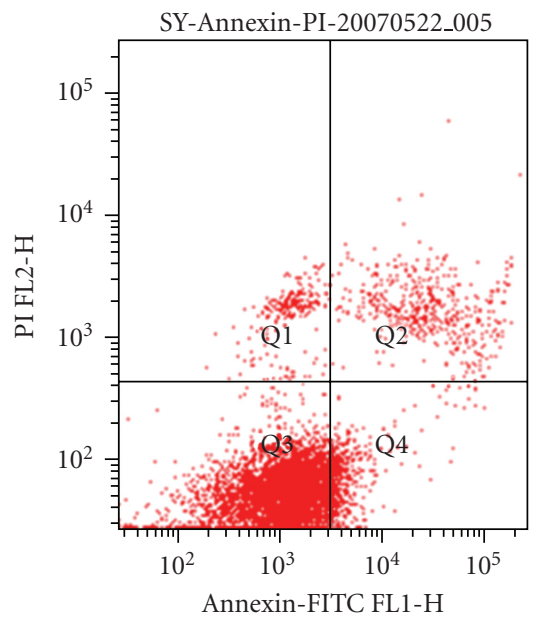

(b)

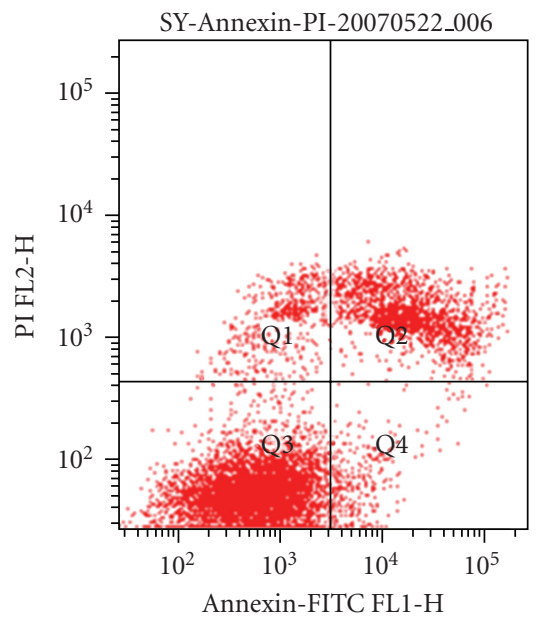

(c)

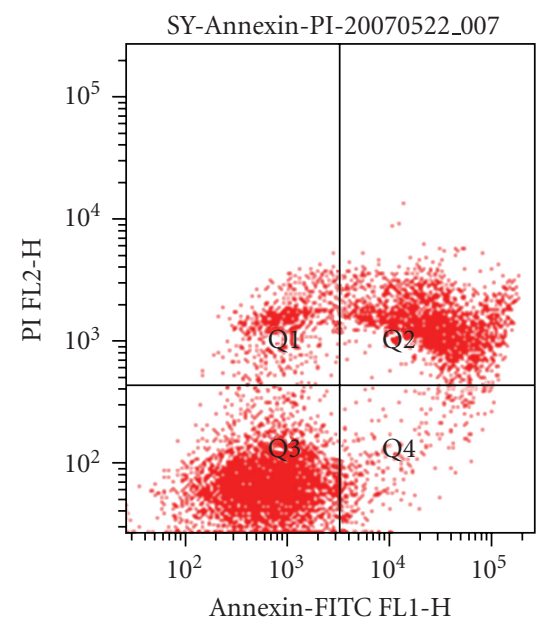

(d)

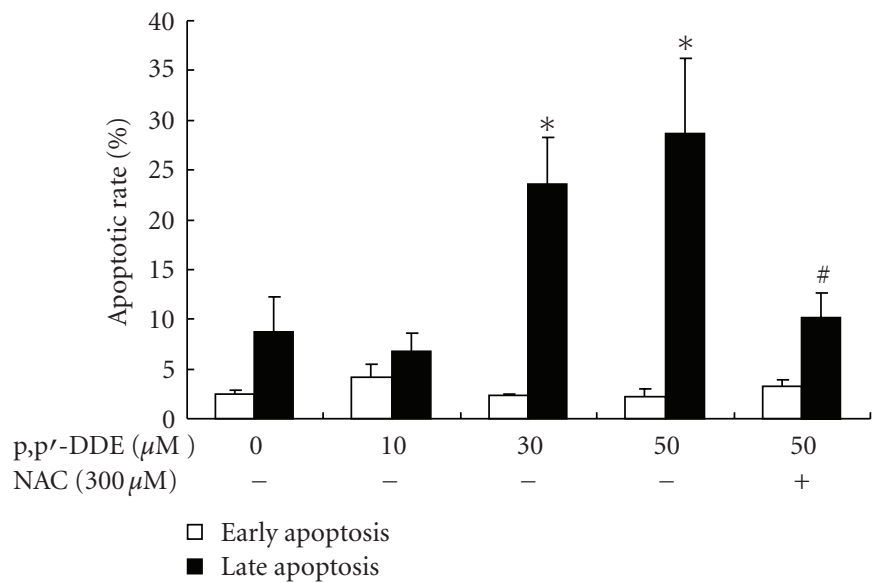

(f)

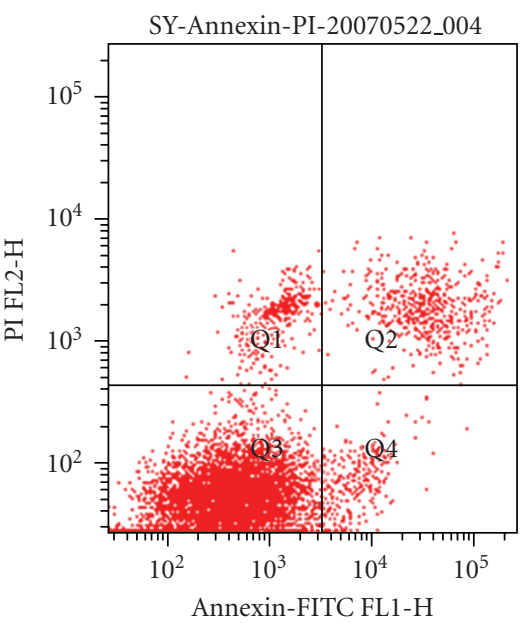

(e) 
The primer sequences were designed according to the related references [18] and cDNA sequence from Genbank (Table 1). All primers were synthesized by the Bioasia Corp (Shanghai, China).

2.6. Western Blotting. Sertoli cells $\left(5 \times 10^{6}\right.$ cells $)$ were lysed in $100 \mu \mathrm{L}$ lysis buffer $(10 \mathrm{mM}$ EDTA, $2 \mathrm{mM}$ EGTA, $20 \mathrm{mM}$ Tris-HCl (pH 7.4), $250 \mathrm{mM}$ sucrose, $0.1 \%$ Triton X-100, $1 \mathrm{mM}$ phenylmethylsulfonyl chloride, and $100 \mathrm{mM}$ PMSF) and scraped from the culture plate to detect FasL and caspase proteins. Each protein sample was measured by a Bio-Rad DC kit (Bio-Rad, Hercules, CA). Cells extracts were separated in SDS-polyacrylamide gel and transferred electrophoretically onto a PVDF membrane. The membranes were blocked in PBS containing 5\% (w/v) nonfat dry milk and then incubated at $4^{\circ} \mathrm{C}$ overnight with anti-FasL (bs0216R, Beijing Biosynthesis Biotechnology Co., Ltd., Beijing, China) at a 1:100 dilution, antiprocaspase-3 (Santa Cruz Biotechnology, Inc., Santa Cruz, CA) at a 1:200 dilution, anti-procaspase-8 (wako, Saitama, Japan) at a 1:200 dilution or anti- $\beta$-actin (Santa Cruz Biotechnology, Inc., Santa Cruz, CA) at 1:200 dilution. Then the membranes were incubated at $37^{\circ} \mathrm{C}$ for 2 hours with the secondary antibody conjugated with horseradish peroxidase (Amersham Pharmacia, Buckinghamshire, UK) diluted at 1:5000. And immune-reactive proteins were detected using ECL western blotting detection system (Pierce Biotechnology Inc., Rockford, IL, USA). Densitometric analysis of immunoblots was performed with Gel pro 3.0 software.

2.7. Analysis of NF- $\kappa B$ Activation by Laser Scanning Confocal Microscope. Sertoli cells were immunofluorescence-labeled according to the manufacturer's instruction using a Cellular NF- $\kappa$ B Translocation Kit (Beyotime Biotech Inc., Nantong, China). Briefly, after washed and fixed, cells were incubated with a blocking buffer for 1 hour to suppress nonspecific binding. Next, cells were incubated with the primary $\mathrm{NF} \kappa \mathrm{B}$ p65 antibody for 1 hour, followed by incubation with a Cy3-conjugated secondary antibody for 1 hour, then with DAPI for 5 minutes before observation. P65 protein and nuclei exhibited red and blue fluorescence, respectively, and could be simultaneously viewed by laser scanning confocal microscope at an excitation wavelength of $350 \mathrm{~nm}$ for DAPI and $540 \mathrm{~nm}$ for $\mathrm{Cy} 3$.

2.8. Statistic Analysis. Results are represented statistically as mean \pm SD. Significance was assessed by ANOVA following appropriate transformation to normalized data and equalized variance where necessary. Mean values were compared by subsequent student-Newman-Keuls (SNKs) using the SPSS statistical package 12.0 (SPSS Inc., Chicago, IL, USA). A difference at $P<.05$ was considered statistically significant. All assays were performed in triplicate.

\section{Results}

3.1. Effect of $p, p^{\prime}-D D E$ on Viability of Rat Sertoli Cells. Sertoli cells were treated with $10,30,50$, or $70 \mu \mathrm{M} \mathrm{p}, \mathrm{p}^{\prime}$-DDE for 24 hours and analyzed with MTT assay. As shown in Figure 1, the viability of Sertoli cells was reduced after treatment with 50 or $70 \mu \mathrm{M}$ p, $\mathrm{p}^{\prime}-\mathrm{DDE}(P<.05)$. In $70 \mu \mathrm{M}$ p, $\mathrm{p}^{\prime}$-DDEtreated group, the cellular viability was about $53.54 \%$ of that in control group. Based on this result, $\mathrm{p}, \mathrm{p}^{\prime}-\mathrm{DDE}$ at concentration of 10,30 , or $50 \mu \mathrm{M}$ was used in subsequent experiments.

3.2. Effect of $p, p^{\prime}-D D E$ on Apoptosis of Rat Sertoli Cells. Sertoli cells were incubated in various concentrations of $\mathrm{p}, \mathrm{p}^{\prime}-\mathrm{DDE}$ $(10,30,50 \mu \mathrm{M})$ for 24 hours. In other experiments, cells were preincubated with $300 \mu \mathrm{M}$ NAC for 1 hour followed by incubation with $50 \mu \mathrm{M}$ p, $\mathrm{p}^{\prime}$-DDE for 24 hours. Then apoptosis was examined by $\mathrm{AO} / \mathrm{EB}$ double staining and flow cytometric analysis.

AO/EB double staining: morphologically, the early apoptotic cells, because of membrane integrity, exhibited stained green with $\mathrm{AO}$, some nuclei exhibited bright condensed or fragmented chromatin, and the late apoptotic cells, because of the lost membrane integrity, were stained red with EB. Sertoli cells with 30 or $50 \mu \mathrm{M}$ p, $\mathrm{p}^{\prime}$-DDE treatment, due to the increase in cell membrane permeability, showed green and red fluorescence and exhibited nucleus fragment, which could be blocked by preincubation with NAC (Figure 2).

Flow cytometric analysis: in our previous study [23], flow cytometric analysis showed that $\mathrm{p}, \mathrm{p}^{\prime}$-DDE caused apoptotic cell death in a dose-dependent manner. After treatment of $50 \mu \mathrm{M}$ p, $\mathrm{p}^{\prime}-\mathrm{DDE}$, apoptosis of rat Sertoli cells reached a peak value of $30 \%$, which could be attenuated by NAC preincubation (Figure 3).

3.3. Effect of p, $p^{\prime}-D D E$ on FasL, Caspase-3 and -8 mRNA in Rat Sertoli Cells. The mRNA levels of FasL and caspase-3 and -8 were determined by RT-PCR in Sertoli cells exposed to different doses of $\mathrm{p}, \mathrm{p}^{\prime}-\mathrm{DDE}$ (i.e., 10,30 , and $50 \mu \mathrm{M}$; see Figures 4(a)-4(c)). Results from denistometric analyses of the intensity of various bands are illustrated in Figure 4 (d). FasL mRNA level in $50 \mu \mathrm{M}$ dose group was significantly higher than that of the control group $(P<.05)$. Caspase3 mRNA levels of Sertoli cells in 30 and $50 \mu \mathrm{M}$ p, $\mathrm{p}^{\prime}$-DDEtreated groups were markedly higher than that of the control group $(P<.05)$. Moreover, compared with the control group, caspase- 8 mRNA levels in different doses of $\mathrm{p}, \mathrm{p}^{\prime}-$ DDE were increased, and the differences were statistically significant $(P<.05)$.

3.4. Effect of p,p'-DDE on FasL and Procaspase-3 and -8 Protein in Rat Sertoli Cells. As seen in Figure 5(d), p, $\mathrm{p}^{\prime}-$ DDE treatment induced an increase of FasL in $50 \mu \mathrm{M}$ dose group. Preincubation with NAC could attenuate this effect successfully $(P<.05)$. A significant reduction was observed in procaspase- 3 over $30 \mu \mathrm{M}$ p, $\mathrm{p}^{\prime}$-DDE and procaspase- 8 over $10 \mu \mathrm{M} \mathrm{p}, \mathrm{p}^{\prime}$-DDE (Figure 5(e)), suggesting the caspase activation, respectively.

3.5. Effect of $p, p^{\prime}-D D E$ on NF- $\kappa B$ Activation in Rat Sertoli Cells. Nuclear translocation of NF- $\kappa \mathrm{B}$ in rat Sertoli cells was observed by laser scanning confocal microscopy. As 
TABLE 1: Description of primers used in the present study.

\begin{tabular}{llll}
\hline Primers & Type & Primer sequence & Length $(\mathrm{bp})$ \\
\hline FasL & forward & $5^{\prime}$-GGAATGGGAAGACACATATGGAACTCC-3' \\
& reverse & $5^{\prime}$-CATATCTGGCCAGTAGTGCAGTAATTC-3' \\
caspase-3 & forward & $5^{\prime}$ - AGTTGGACCCACCTTGTGAG $-3^{\prime}$ & 238 \\
& reverse & $5^{\prime}-$ AGTCTGCAGCTCCTCCACAT $-3^{\prime}$ \\
caspase-8 & forward & $5^{\prime}-$ TCGACGATTACGAACGATCA $-3^{\prime}$ \\
& reverse & $5^{\prime}$ - CAGTCTTTGCCCTTGTGGTC $-3^{\prime}$ & 409 \\
& forward & $5^{\prime}$ - CGTTGACATCCGTAAAGAC $-3^{\prime}$ & 201 \\
\hline
\end{tabular}

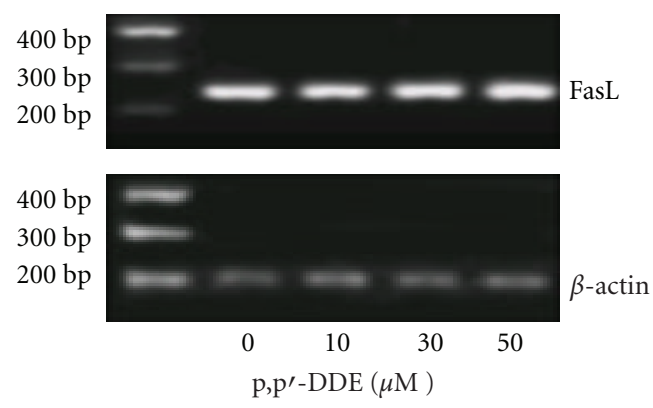

(a)

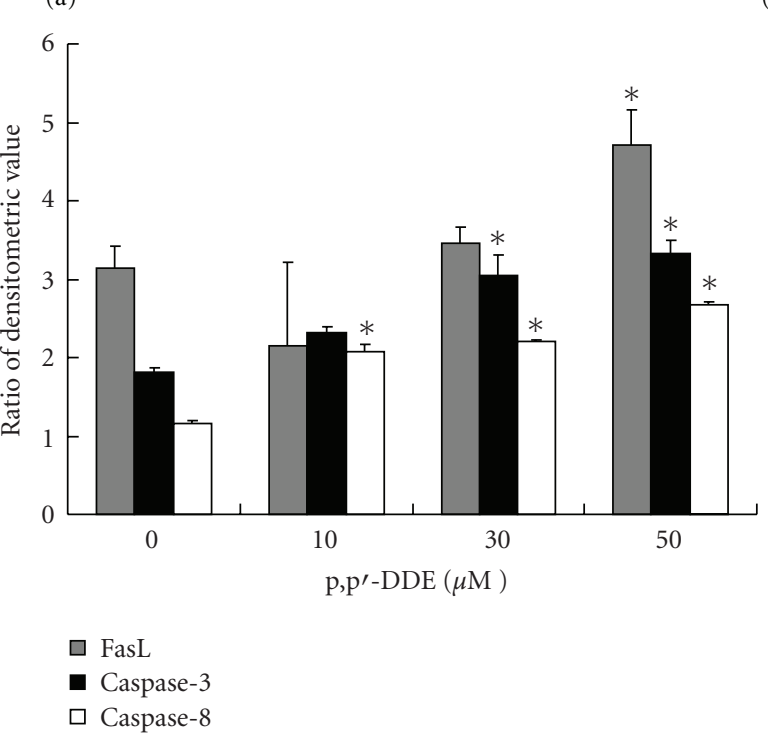

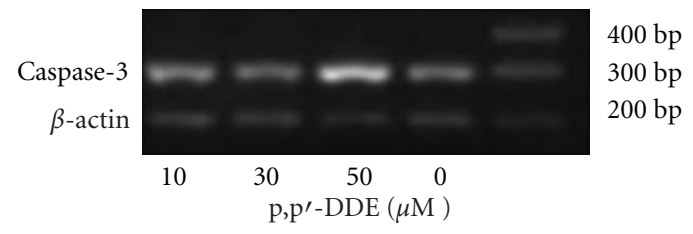

(b)

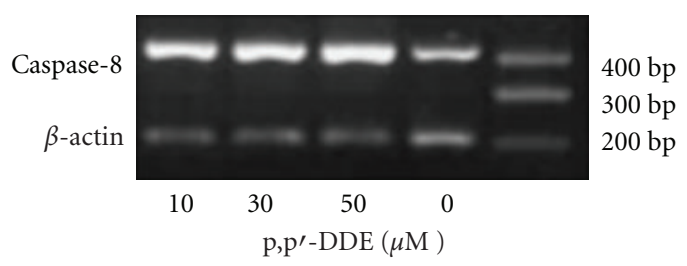

(c)

(d)

FIGURE 4: Effects of different p,p'-DDE concentrations on the FasL and caspase-3 and -8 mRNA in rat Sertoli cells by RT-PCR (a)-(c). Quantitative analysis of FasL and caspase-3 and - 8 mRNA levels of rat Sertoli cells exposed to different doses of p,p'-DDE (d). The data were obtained from the bands on the gels that were measured by densitometric analysis and standardized by comparison to the $\beta$-actin control using Biocapt MV software analysis system. Significant difference is $\left(^{*}\right) P<.05$, compared with the control group.

seen in Figure 6, morphologically, p65 protein and nuclei exhibited red and blue fluorescence, respectively, and could be simultaneously viewed under laser scanning confocal microscope. The activation of NF- $\kappa \mathrm{B}$ enhanced with the increase of $\mathrm{p}, \mathrm{p}^{\prime}$-DDE dose.

\section{Discussion}

In the present study, $\mathrm{p}, \mathrm{p}^{\prime}$-DDE could induce apoptosis of Sertoli cells through a FasL-dependent pathway including nuclear translocation of NF- $\kappa \mathrm{B}$, increase of the FasL 


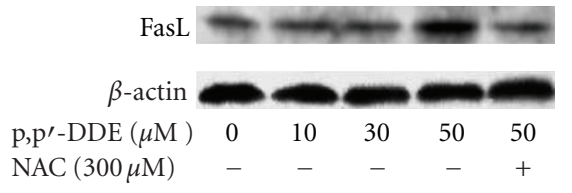

(a)

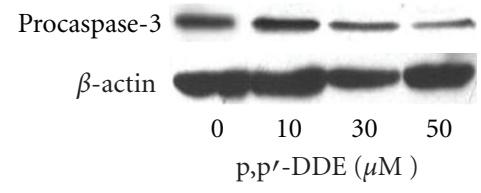

(b)

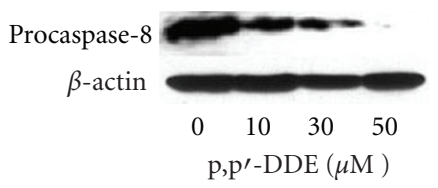

(c)
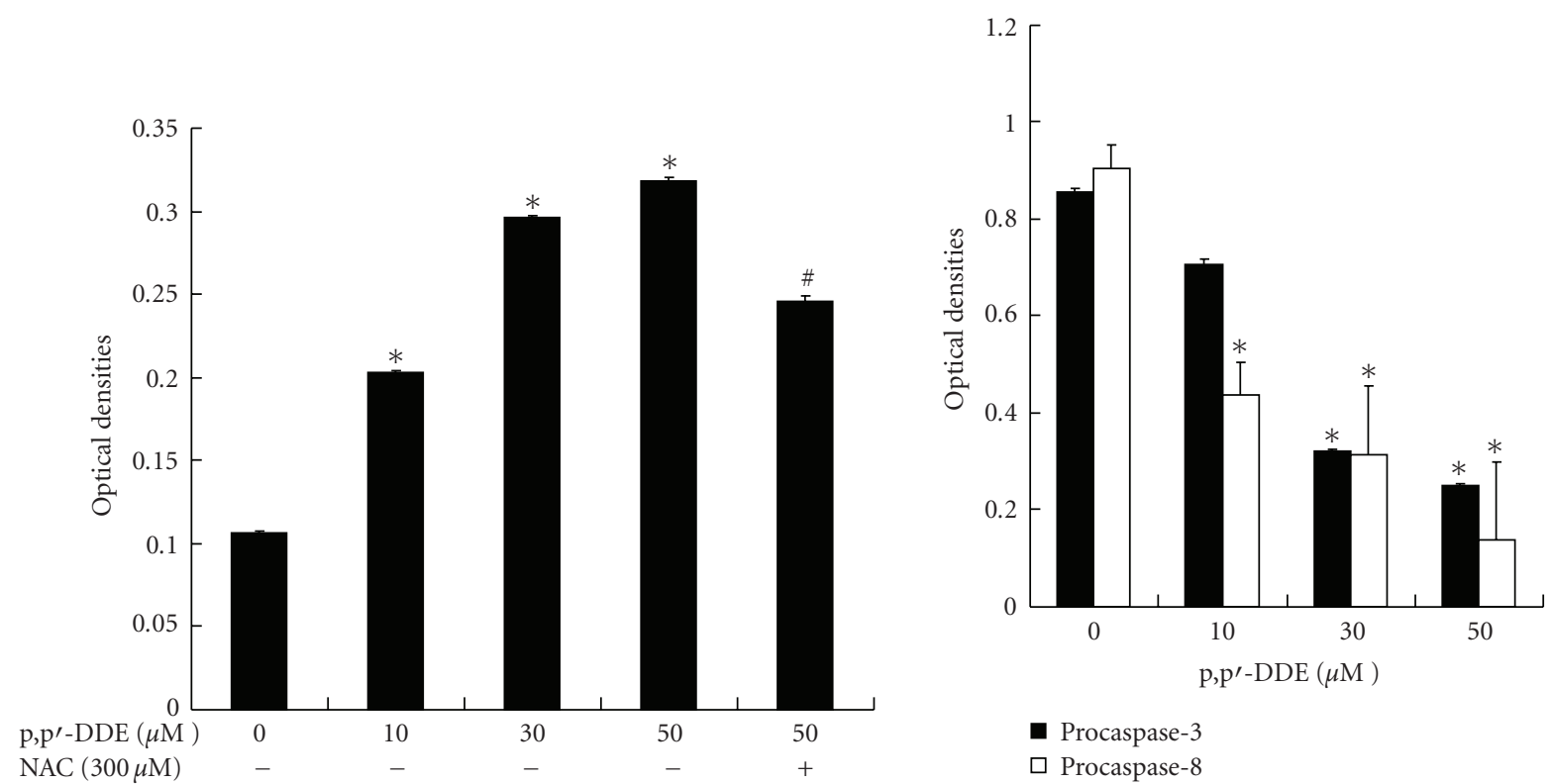

(d)

(e)

FIGURE 5: (a) Effect of NAC on p,p'-DDE-induced FasL protein. Sertoli cells were treated with p, p'-DDE pretreated with or without NAC. Protein from whole cell lysates was used in Western blotting for FasL detection. (b)-(c) Procaspase-3 and -8 in Sertoli cells exposed to $\mathrm{p}, \mathrm{p}^{\prime}$-DDE for 24 hours. Protein from whole cell lysates was used in Western blotting for procaspase-3 and -8 detection. (d)-(e) Quantitative analysis of the immunoreactive FasL and procaspase- 3 and -8 . Data are indicated as mean \pm SD. Significant difference is $(*) P<.05$, compared with the control group is $\left(^{\#}\right) P<.05$, compared with $50 \mu \mathrm{M}$ p, $\mathrm{p}^{\prime}$-DDE group.

expression, and activation of the caspase- 8 and -3. Importantly, the antioxidant NAC could attenuate most of these changes.

Recent discoveries have significantly advanced the understanding of biochemical and genetic requirements of distinct apoptosis pathways (i.e., mitochondria, death-receptor, and endoplasmic reticulum-mediated apoptosis) and their dysregulation in disease [25]. In the case of death-receptor, there are several members that belong to tumor necrosis factor (TNF) receptor superfamily, including Fas (CD95, Apol), TNFR1 (p55, CD120a), and death receptors 3, 4, and 5 (DR3, 4 , and 5).

The Fas system is a widely recognized apoptosis signal transduction pathway in which a ligand-receptor interaction triggers the cell death pathway [26]. Fas is a surface receptor that triggers apoptotic cell death when cross-linked by FasL $[27,28]$. Ligation of FasL to Fas in the cell membrane triggers activation of caspase- 8 . Once activated, caspase- 8 transduces a signal to effector caspases, including caspases-3, -6, and -7, and eventually leads to the hydrolysis of cytosolic and nuclear substrates [29].
The impact of organochlorine pesticides (OCPs) on the reproductive function was put forward in 1967 by Ratcliffe [30], who is the first to report eggshell thinning in some raptorial species. DDT is a principal organochlorine compound used for a long time as an insecticide. It can impair the male reproductive health by possible mechanism of antiandrogen effect. Animal experiment demonstrated that exposure of rats to 50 and $100 \mathrm{mg} \mathrm{DDT} / \mathrm{kg}$ b.wt during 10 consecutive days induced reproductive toxicology. The relative weight of testes and the number as well as the motility of epididymal spermatozoa were reduced. Meanwhile, FSH and LH of serum were increased [31]. The present study demonstrated that $\mathrm{p}, \mathrm{p}^{\prime}$-DDE could induce a concentrationdependent increase in apoptosis of rat Sertoli cells.

In the normal state, Sertoli cells express a basal level of FasL, which triggers apoptosis of a few Fas-positive germ cells. Some literatures point out that Sertoli cells also express Fas, and germ cells express FasL $[32,33]$. Sertoli cells have such multiple functions as providing the cytoarchitectural support and microenvironment for developing germ cells. If Sertoli cells are injured and the supporting capacity of Sertoli 


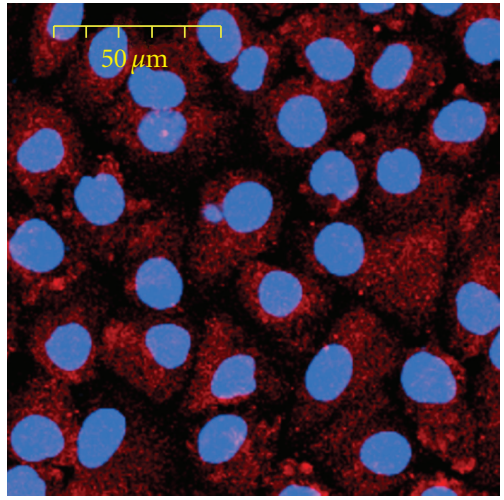

(a) Control

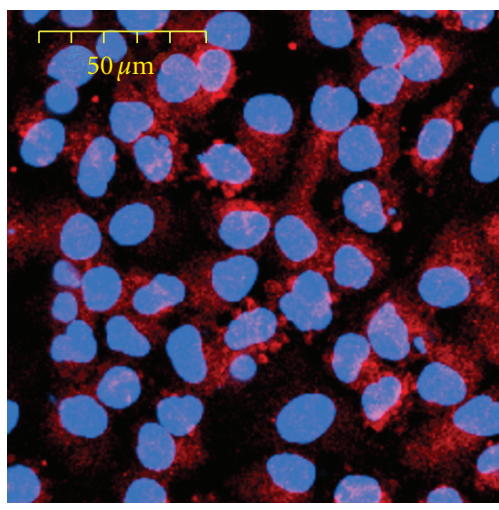

(c) $\mathrm{p}, \mathrm{p}^{\prime}-\mathrm{DDE} 30 \mu \mathrm{M}$

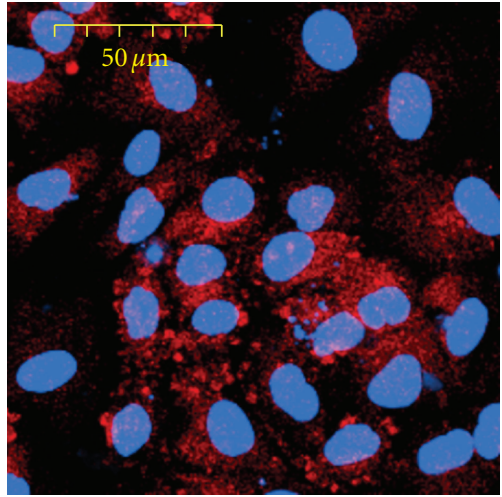

(b) $\mathrm{p}, \mathrm{p}^{\prime}-\mathrm{DDE} 10 \mu \mathrm{M}$

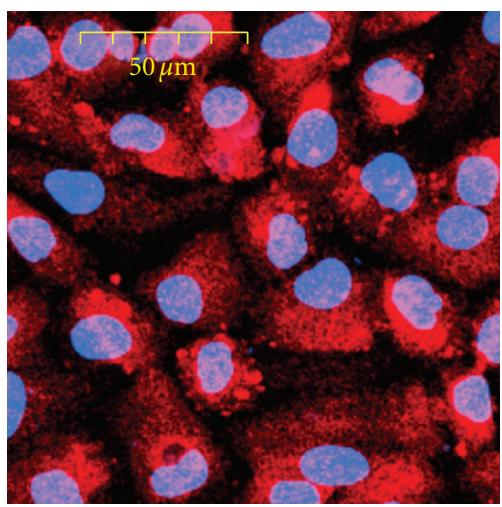

(d) $\mathrm{p}, \mathrm{p}^{\prime}$-DDE $50 \mu \mathrm{M}$

Figure 6: Effect of $\mathrm{p}, \mathrm{p}^{\prime}$-DDE on NF- $\kappa \mathrm{B}$ activation in rat Sertoli cells by laser scanning confocal microscope $(40 \times)$. Representative images for NF- $\kappa \mathrm{B}$ activation in control (a), $10 \mu \mathrm{M}$ (b), $30 \mu \mathrm{M}$ (c), and $50 \mu \mathrm{M}$ (d) p, $\mathrm{p}^{\prime}$-DDE-treated groups. There was a dose-dependent increase in nuclear translocation of NF- $\kappa$ B in Sertoli cells. In $50 \mu \mathrm{M}$ p, $\mathrm{p}^{\prime}$-DDE-treated group, the nuclear translocation was more pronounced.

cells is reduced, germ cells cannot be supported adequately [18]. Our results demonstrated that FasL mRNA level for $50 \mu \mathrm{M}$ dose group was significantly higher than that of the control group, and FasL protein levels increased with the increase of dose of toxicant after the cells were incubated by various concentrations of $\mathrm{p}, \mathrm{p}^{\prime}$-DDE for 24 hours. This result indicated that FasL mRNA levels increased and could lead to the enhancement of FasL protein expression, then activate the Fas system, and eventually lead to the apoptosis of Sertoli cells and abnormality of spermatogenesis, which might be a possible mechanism elucidating male reproductive abnormality caused by $\mathrm{p}, \mathrm{p}^{\prime}$-DDE. Similar studies were reported by previous findings for other categories of toxicants such as mono-(2-ethylhexyl) phthalate, 2, 5-hexanedione [18], Diethylstilbestrol [34], and carbon disulfide [35].

$\mathrm{NF}-\kappa \mathrm{B}$ is present as a dimer of protein components (p65/p50) in a latent/inactive form, bound to inhibitory protein I $\kappa$ B in the cytoplasm [36]. Stimulation by a variety of extracellular signals leads to degradation of the $\mathrm{I} \kappa \mathrm{B}$. The liberated NF- $\kappa \mathrm{B}$ then rapidly translocates to the nucleus, where it regulates transcription by binding to consensus $\kappa \mathrm{B}$ sites in the promoters of the target genes [37]. In the rat testis, the NF- $\kappa \mathrm{B}$ complex of $\mathrm{p} 65$ and p50 proteins is found to be constitutively expressed in the nuclei of Sertoli cells at all stages of spermatogenesis [38]. Interestingly, NF- $\kappa$ B can exert both pro- and antiapoptotic effects in different cells types [39]. Whether NF- $\kappa$ B promotes or inhibits apoptosis seems to depend on the specific cell type and the type of the inducer. Numerous reports suggest that NF- $\kappa \mathrm{B}$ performs a proapoptotic role. NF- $\kappa \mathrm{B}$ p65 complex can directly stimulate the expression of apoptosis-inducible genes such as Fas, FasL, and death receptors 4 and 5 [40]. For example, the promoters of the mouse FasL have $\kappa \mathrm{B}$ sites and can be upregulated by activation-induced cell death in T cells [41]. Kasibhatla demonstrated in Jurkat $\mathrm{T}$ cells that activation of NF- $\kappa B$ and AP-1 and their transactivation of FasL regulated VP16- and VM-26-induced apoptosis via the expression of FasL [42]. Our study demonstrated that in vitro exposure to $\mathrm{p}, \mathrm{p}^{\prime}$ DDE could induce an increase in NF- $\kappa$ B activation and the expression of FasL in rat Sertoli cells. The results suggested that NF- $\kappa$ B could promote cell apoptosis through the FasLdependent pathway in vitro exposure to $\mathrm{p}, \mathrm{p}^{\prime}-\mathrm{DDE}$ in rat Sertoli cells.

There is a general agreement that male reproductive organs are particularly susceptible to the deleterious effects of reactive oxygen species (ROS) and lipid peroxidation, which ultimately lead to impaired fertility [43]. Recent literature suggests that ROS as a signaling molecule can induce 


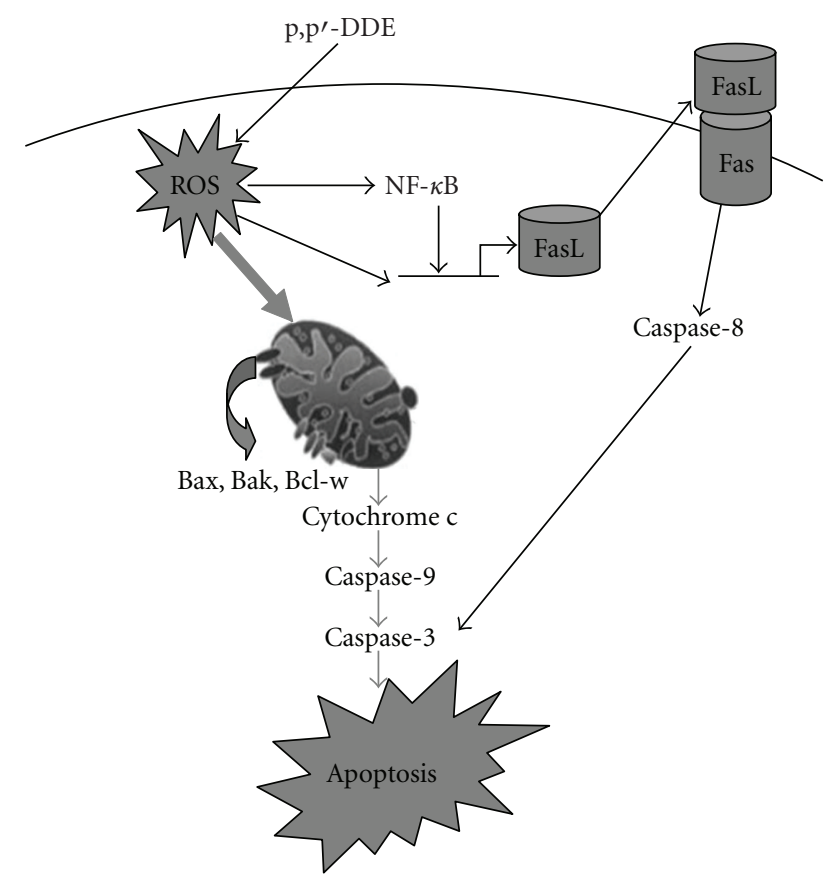

FIGURE 7: Proposed model of p, $\mathrm{p}^{\prime}$-DDE-induced signaling pathways leading to apoptosis. ROS generation might play a critical role in the initiation of $\mathrm{p}, \mathrm{p}^{\prime}$-DDE-induced apoptosis of Sertoli cells through two mechanisms, one was the mitochondria-mediated pathway including elevation of ROS, decrease in $\Delta \Psi_{m}$ along with the cytochrome c release from mitochondria into the cytosol, and activation of the caspase- 9 and -3 in our previous study; and the other was the elevation of ROS, which resulted in activation of $\mathrm{NF}-\kappa \mathrm{B}$, expression of FasL and triggered FasL-dependent pathway (FasL/caspase-8/-3 signaling module) in our present study.

downstream apoptotic processes [44]. ROS are key mediators of signaling pathways, such as the NF- $\kappa$ B pathway [45]. Wang et al. [46] reported that oxidative stress enhanced $N F-\kappa B$ activation. NF- $\kappa \mathrm{B}$ is a redox-regulated transcription factor, and $\mathrm{NF}-\kappa \mathrm{B}$ heterodimer activation requires $\mathrm{I} \kappa \mathrm{B}$ cleavage, which needs an oxidizing milieu [47]. Moreover, ROS are shown to be able to increase FasL expression. Conversely, various antioxidants potently inhibit the FasL expression [48]. In our previous studies, $\mathrm{p}, \mathrm{p}^{\prime}$-DDE could induce apoptosis of Sertoli cells via activation of mitochondriamediated pathway including elevation of ROS, decrease in $\Delta \Psi_{m}$ and SOD activity, and increase in the leakage rate of LDH and MDA level [23]. Our present study demonstrated that in vitro exposure to $\mathrm{p}, \mathrm{p}^{\prime}$-DDE could induce increase of FasL in rat Sertoli cells, and preincubation with NAC could attenuate this effect successfully. All of our studies suggested that ROS generation might play a critical role in the initiation of $\mathrm{p}, \mathrm{p}^{\prime}$-DDE-induced apoptosis of Sertoli cells through mitochondria-mediated and FasL-dependent pathway (Figure 7).

Caspases are a family of cysteine proteases that are a central component of the apoptotic machinery. Caspases are synthesized as inactive precursors (procaspases) that are cleaved at specific aspartate residues to generate the active subunits. Among FasL-dependent apoptosis, caspase8 plays the most important role in transduction of death signals [49]. Paasch et al. demonstrates that the signal that transmits caspase- 8 is also present during spermatogenesis [50]. Giammona et al. [51] have indicated that Mono-(2ethylhexyl) phthalate (MEHP), a well-characterized Sertoli cell toxicant, can decrease levels of procaspase- 8 and increase levels of procaspase- 8 cleavage products in mice testis. This result is consistent with our study in which in vitro exposure to $\mathrm{p}, \mathrm{p}^{\prime}$-DDE induces in rat Sertoli cells an increase in caspase- 8 mRNA levels and a reduction in procaspase8 protein levels. In addition, caspase- 3 is one of the pivotal proteinases that initiate cell apoptosis [52]. Activated caspase- 3 can interact with a large number of targets within an affected cell to bring about its destruction by apoptosis [53]. Dalgaard et al. [54] observed an increased activity of caspase- 3 in the rat testis, 3 hours and 12 hours after $0.4 \mathrm{mg} / \mathrm{g}$ of MEHP-exposure. Our result demonstrated that in vitro exposure to $\mathrm{p}, \mathrm{p}^{\prime}$-DDE could induce an increase in caspase- 3 mRNA levels and a reduction in procaspase- 3 protein levels in rat Sertoli cells. These results indicated that caspases were activated in p, $\mathrm{p}^{\prime}$-DDE-induced apoptosis of Sertoli cells.

The present data indicated that $\mathrm{p}, \mathrm{p}^{\prime}$-DDE could induce apoptosis of rat Sertoli cells through a FasL-dependent pathway. There are three major apoptosis pathways in the mammalian cells: mitochondria, death-receptor, and endoplasmic reticulum-mediated apoptosis. It is unlikely that a single mechanism regulates apoptosis in the testis, but rather that multiple apoptotic pathways are involved in the complex process of apoptosis. Our previous study also demonstrated that $\mathrm{p}, \mathrm{p}^{\prime}$-DDE could induce mitochondriamediated apoptosis in Sertoli cells [23]. Some studies showed the cell apoptosis through endoplasmic reticulum-mediated pathway in the rat testis [55-57]. Hence it is noted that endoplasmic reticulum-mediated apoptosis pathway and relationship among three apoptosis pathways in rat Sertoli cells exposure to $\mathrm{p}, \mathrm{p}^{\prime}$-DDE should be regarded as priority in the next studies.

In conclusion, $\mathrm{p}, \mathrm{p}^{\prime}$-DDE induces increases in apoptotic rate of Sertoli cells by a mechanism possibly involving FasLdependent pathway. In vitro exposure to $\mathrm{p}, \mathrm{p}^{\prime}$-DDE can enhance ROS and oxidative stress, then induce an increase in NF- $\kappa \mathrm{B}$ activation, FasL mRNA, and protein levels in rat Sertoli cells. Upon engagement of FasL to Fas, an intrinsic program of apoptotic death is stimulated in a target cell leading to the activation of caspase-8. Finally, apoptosis of Sertoli cells is mediated by a terminal executioner, caspase-3, thereby disturbing the spermatogenic process. The detailed disrupting mechanism, of course, needs further investigation. The present study has provided preliminary but important data for further study of reproductive endocrine disorder resulting from environmental EDCs.

\section{Acknowledgments}

This work was supported by the Key Funding from the National Natural Science Foundation of China (40590390) and the National Natural Science Foundation of China (30671734). 


\section{References}

[1] M. C. Fossi, S. Casini, and L. Marsili, "Potential toxicological hazard due to endocrine-disrupting chemicals on Mediterranean top predators: state of art, gender differences and methodological tools," Environmental Research, vol. 104, no. 1, pp. 174-182, 2007.

[2] H. Ishibashi, K. Tachibana, M. Tsuchimoto, et al., "In vivo testing system for determining the estrogenic activity of endocrine-disrupting chemicals (EDCs) in goldfish (Carassius auratus)," Journal of Health Science, vol. 47, no. 2, pp. 213-218, 2001.

[3] O. Dyer, "Decline in male fertility may be linked to insecticide," British Medical Journal, vol. 311, no. 6996, pp. 11-12, 1995.

[4] A. Daxenberger, "Pollutants with androgen-disrupting potency," European Journal of Lipid Science and Technology, vol. 104, no. 2, pp. 124-130, 2002.

[5] T. A. Albanis, D. Hela, G. Papakostas, and V. Goutner, "Concentration and bioaccumulation of organochlorine pesticide residues in herons and their prey in wetlands of Thermaikos Gulf, Macedonia, Greece," Science of the Total Environment, vol. 182, no. 1-3, pp. 11-19, 1996.

[6] G. W. Feist, M. A. H. Webb, D. T. Gundersen, et al., "Evidence of detrimental effects of environmental contaminants on growth and reproductive physiology of white sturgeon in impounded areas of the Columbia River," Environmental Health Perspectives, vol. 113, no. 12, pp. 1675-1682, 2005.

[7] M.-J. Lopez-Espinosa, E. Lopez-Navarrete, A. Rivas, et al., "Organochlorine pesticide exposure in children living in southern Spain," Environmental Research, vol. 106, no. 1, pp. $1-6,2008$.

[8] L. Lopez-Carrillo, L. Torres-Arreola, L. Torres-Sanchez, et al., "Is DDT use a public health problem in Mexico?" Environmental Health Perspectives, vol. 104, no. 6, pp. 584-588, 1996.

[9] L. Rivero-Rodriguez, V. H. Borja-Aburto, C. Santos-Burgoa, S. Waliszewskiy, C. Rios, and V. Cruz, "Exposure assessment for workers applying DDT to control malaria in Veracruz, Mexico," Environmental Health Perspectives, vol. 105, no. 1, pp. 98-101, 1997.

[10] R. S. Aulakh, J. S. Bedi, J. P. S. Gill, B. S. Joia, P. A. Pooni, and J. K. Sharma, "Occurrence of DDT and HCH insecticide residues in human biopsy adipose tissues in Punjab, India," Bulletin of Environmental Contamination and Toxicology, vol. 78, no. 5, pp. 330-334, 2007.

[11] W. R. Kelce, C. R. Stone, S. C. Laws, L. E. Gray, J. A. Kemppainen, and E. M. Wilson, "Persistent DDT metabolite p, $\mathrm{p}^{\prime}-\mathrm{DDE}$ is a potent androgen receptor antagonist," Nature, vol. 375 , no. 6532 , pp. 581-585, 1995.

[12] L. E. Gray Jr. and W. R. Kelce, "Latent effects of pesticides and toxic substances on sexual differentiation of rodents," Toxicology and Industrial Health, vol. 12, no. 3-4, pp. 515-531, 1996.

[13] O. Tebourbi, K. B. Rhouma, and M. Sakly, "DDT induces apoptosis in rat thymocytes," Bulletin of Environmental Contamination and Toxicology, vol. 61, no. 2, pp. 216-223, 1998.

[14] D. J. Allan, B. V. Harmon, and S. A. Roberts, "Spermatogonial apoptosis has three morphologically recognizable phases and shows no circadian rhythm during normal spermatogenesis in the rat," Cell Proliferation, vol. 25, no. 3, pp. 241-250, 1992.

[15] W. W. Lin, L. I. Lipshultz, D. J. Lamb, E. D. Kim, and T. M. Wheeler, "In situ end-labeling of human testicular tissue demonstrates increased apoptosis in conditions of abnormal spermatogenesis," Fertility and Sterility, vol. 68, no. 6, pp. 1065-1069, 1997.

[16] R. M. Wilson and M. D. Griswold, "Secreted proteins from rat Sertoli cells," Experimental Cell Research, vol. 123, no. 1, pp. 127-135, 1979.

[17] M. D. Griswold, C. Morales, and S. R. Sylvester, "Molecular biology of the Sertoli cell," Oxford Reviews of Reproductive Biology, vol. 10, pp. 124-161, 1988.

[18] J. Lee, J. H. Richburg, E. B. Shipp, M. L. Meistrich, and K. Boekelheide, "The Fas system, a regulator of testicular germ cell apoptosis, is differentially up-regulated in Sertoli cell versus germ cell injury of the testis," Endocrinology, vol. 140, no. 2, pp. 852-858, 1999.

[19] L. D. Russell and R. N. Peterson, "Determination of the elongate spermatid-Sertoli cell ratio in various mammals," Journal of Reproduction and Fertility, vol. 70, no. 2, pp. 635641, 1984.

[20] J. C. O'Connor, S. R. Frame, L. G. Davis, and J. C. Cook, "Detection of the environmental antiandrogen $p, p^{\prime}$-DDE in $\mathrm{CD}$ and long-evans rats using a Tier I screening battery and a Hershberger assay," Toxicological Sciences, vol. 51, no. 1, pp. 44-53, 1999.

[21] Y. Makita, M. Omura, A. Tanaka, and C. Kiyohara, "Effects of concurrent exposure to tributyltin and 1,1-dichloro-2,2 bis ( $\mathrm{p}$ chlorophenyl) ethylene ( $\mathrm{p}, \mathrm{p}^{\prime}$-DDE) on immature male Wistar rats," Basic \& Clinical Pharmacology \& Toxicology, vol. 97, no. 6, pp. 364-368, 2005.

[22] X. Xiong, A. Wang, G. Liu, et al., "Effects of p,p'dichlorodiphenyldichloroethylene on the expressions of transferrin and androgen-binding protein in rat Sertoli cells," Environmental Research, vol. 101, no. 3, pp. 334-339, 2006.

[23] Y. Song, X. Liang, Y. Hu, Y. Wang, H. Yu, and K. Yang, "p,p' DDE induces mitochondria-mediated apoptosis of cultured rat Sertoli cells," Toxicology, vol. 253, no. 1-3, pp. 53-61, 2008.

[24] J. P. Mather, K. M. Attie, T. K. Woodruff, G. C. Rice, and D. M. Phillips, "Activin stimulates spermatogonial proliferation in germ-Sertoli cell cocultures from immature rat testis," Endocrinology, vol. 127, no. 6, pp. 3206-3214, 1990.

[25] P. T. Daniel, "Dissecting the pathways to death," Leukemia, vol. 14, no. 12, pp. 2035-2044, 2000.

[26] H. Feng, Y. Zeng, M. W. Graner, L. Whitesell, and E. Katsanis, "Evidence for a novel, caspase-8-independent, Fas death domain-mediated apoptotic pathway," Journal of Biomedicine and Biotechnology, vol. 2004, no. 1, pp. 41-51, 2004.

[27] S. Nagata and P. Golstein, "The Fas death factor," Science, vol. 267, no. 5203, pp. 1449-1456, 1995.

[28] S. Nagata, "Apoptosis by death factor," Cell, vol. 88, no. 3, pp. 355-365, 1997.

[29] R. De Maria, L. Lenti, F. Malisan, et al., "Requirement for GD3 ganglioside in CD95- and ceramide-induced apoptosis," Science, vol. 277, no. 5332, pp. 1652-1655, 1997.

[30] D. A. Ratcliffe, "Decrease in eggshell weight in certain birds of prey," Nature, vol. 215, no. 5097, pp. 208-210, 1967.

[31] K. Ben Rhouma, O. Tébourbi, R. Krichah, and M. Sakly, "Reproductive toxicity of DDT in adult male rats," Human \& Experimental Toxicology, vol. 20, no. 8, pp. 393-397, 2001.

[32] S. Ogi, N. Tanji, M. Yokoyama, M. Takeuchi, and N. Terada, "Involvement of Fas in the apoptosis of mouse germ cells induced by experimental cryptorchidism," Urological Research, vol. 26, no. 1, pp. 17-21, 1998.

[33] R. Nair and C. Shaha, "Diethylstilbestrol induces rat spermatogenic cell apoptosis in vivo through increased expression of spermatogenic cell Fas/FasL system," The Journal of Biological Chemistry, vol. 278, no. 8, pp. 6470-6481, 2003. 
[34] A. D’Alessio, A. Riccioli, P. Lauretti, et al., "Testicular FasL is expressed by sperm cells," Proceedings of the National Academy of Sciences of the United States of America, vol. 98, no. 6, pp. 3316-3321, 2001.

[35] J. Deng, G.-Y. Chen, J.-J. Ji, et al., "Apoptosis and gene FasL expression induced by carbon disulfide in rat steroli cells," Zhonghua Lao Dong Wei Sheng Zhi Ye Bing Za Zhi, vol. 24, no. 12, pp. 730-733, 2006.

[36] S. Shalini and M. P. Bansal, "Alterations in selenium status influences reproductive potential of male mice by modulation of transcription factor NF $\kappa$ B," BioMetals, vol. 20, no. 1, pp. 4959, 2007.

[37] J. Wang, S. Kannan, H. Li, and M. F. Khan, "Cytokine gene expression and activation of NF- $\kappa \mathrm{B}$ in aniline-induced splenic toxicity," Toxicology and Applied Pharmacology, vol. 203, no. 1, pp. 36-44, 2005.

[38] V. Pentikäinen, L. Suomalainen, K. Erkkilä, et al., "Nuclear factor- $\kappa \mathrm{B}$ activation in human testicular apoptosis," American Journal of Pathology, vol. 160, no. 1, pp. 205-218, 2002.

[39] M. Barkett and T. D. Gilmore, "Control of apoptosis by Rel/NF- $\kappa$ B transcription factors," Oncogene, vol. 18, no. 49, pp. 6910-6924, 1999.

[40] J. Kucharczak, M. J. Simmons, Y. Fan, and C. Gélinas, “To be, or not to be: NF- $\kappa$ B is the answer-role of Rel/NF- $\kappa$ B in the regulation of apoptosis," Oncogene, vol. 22, no. 56, pp. 89618982, 2003.

[41] K. Matsui, A. Fine, B. Zhu, A. Marshak-Rothstein, and S.-T. Ju, "Identification of two NF- $\kappa$ B sites in mouse CD95 ligand (Fas ligand) promoter: functional analysis in T cell hybridoma," The Journal of Immunology, vol. 161, no. 7, pp. 3469-3473, 1998.

[42] S. Kasibhatla, T. Brunner, L. Genestier, F. Echeverri, A. Mahboubi, and D. R. Green, "DNA damaging agents induce expression of Fas ligand and subsequent apoptosis in $\mathrm{T}$ lymphocytes via the activation of NF- $\kappa$ B and AP-1," Molecular Cell, vol. 1, no. 4, pp. 543-551, 1998.

[43] K. Williams, J. Frayne, E. A. McLaughlin, and L. Hall, "Expression of extracellular superoxide dismutase in the human male reproductive tract, detected using antisera raised against a recombinant protein," Molecular Human Reproduction, vol. 4, no. 3, pp. 235-242, 1998.

[44] D.-X. Hou, M. Fujii, N. Terahara, and M. Yoshimoto, "Molecular mechanisms behind the chemopreventive effects of anthocyanidins," Journal of Biomedicine and Biotechnology, vol. 2004, no. 5, pp. 321-325, 2004.

[45] Y. K. Nakamura and S. T. Omaye, " $\alpha$-tocopherol modulates human umbilical vein endothelial cell expression of $\mathrm{Cu} / \mathrm{Zn}$ superoxide dismutase and catalase and lipid peroxidation," Nutrition Research, vol. 28, no. 10, pp. 671-680, 2008.

[46] J. Wang, G. Wang, G. A. S. Ansari, and M. F. Khan, "Activation of oxidative stress-responsive signaling pathways in early splenotoxic response of aniline," Toxicology and Applied Pharmacology, vol. 230, no. 2, pp. 227-234, 2008.

[47] C. Napoli, F. De Nigris, and W. Palinski, "Multiple role of reactive oxygen species in the arterial wall," Journal of Cellular Biochemistry, vol. 82, no. 4, pp. 674-682, 2001.

[48] M. K. A. Bauer, M. Vogt, M. Los, J. Siegel, S. Wesselborg, and K. Schulze-Osthoff, "Role of reactive oxygen intermediates in activation-induced CD95 (APO-1/Fas) ligand expression," The Journal of Biological Chemistry, vol. 273, no. 14, pp. 80488055, 1998.

[49] T. M. Said, U. Paasch, H.-J. Glander, and A. Agarwal, "Role of caspases in male infertility," Human Reproduction Update, vol. 10, no. 1, pp. 39-51, 2004.
[50] U. Paasch, S. Grunewald, K. Wuendrich, and H. J. Glander, "Caspases are associated with apoptosis in human ejaculated spermatozoa and in spermatogenesis," in Andrology in the 21st Century, Short Communications, pp. 59-64, 2001.

[51] C. J. Giammona, P. Sawhney, Y. Chandrasekaran, and J. H. Richburg, "Death receptor response in rodent testis after mono-(2-ethylhexyl) phthalate exposure," Toxicology and Applied Pharmacology, vol. 185, no. 2, pp. 119-127, 2002.

[52] S. M. Khan, L. M. Dauffenbach, and J. Yeh, "Mitochondria and caspases in induced apoptosis in human luteinized granulosa cells," Biochemical and Biophysical Research Communications, vol. 269, no. 2, pp. 542-545, 2000.

[53] A. Philchenkov, "Caspases: potential targets for regulating cell death," Journal of Cellular and Molecular Medicine, vol. 8, no. 4, pp. 432-444, 2004.

[54] M. Dalgaard, C. Nellemann, H. R. Lam, I. K. Sørensen, and O. Ladefoged, "The acute effects of mono(2-ethylhexyl)phthalate (MEHP) on testes of prepubertal Wistar rats," Toxicology Letters, vol. 122, no. 1, pp. 69-79, 2001.

[55] T. M. Onorato, P. W. Brown, and P. L. Morris, "Mono-(2ethylhexyl) phthalate increases spermatocyte mitochondrial peroxiredoxin 3 and cyclooxygenase 2," Journal of Andrology, vol. 29, no. 3, pp. 293-303, 2008.

[56] M. Muguruma, M. Yamazaki, M. Okamura, M. Moto, Y. Kashida, and K. Mitsumori, "Molecular mechanism on the testicular toxicity of 1,3-dinitrobenzene in Sprague-Dawley rats: preliminary study," Archives of Toxicology, vol. 79, no. 12, pp. 729-736, 2005.

[57] P. J. Hughes, H. McLellan, D. A. Lowes, et al., "Estrogenic alkylphenols induce cell death by inhibiting testis endoplasmic reticulum $\mathrm{Ca}^{2+}$ pumps," Biochemical and Biophysical Research Communications, vol. 277, no. 3, pp. 568-574, 2000. 

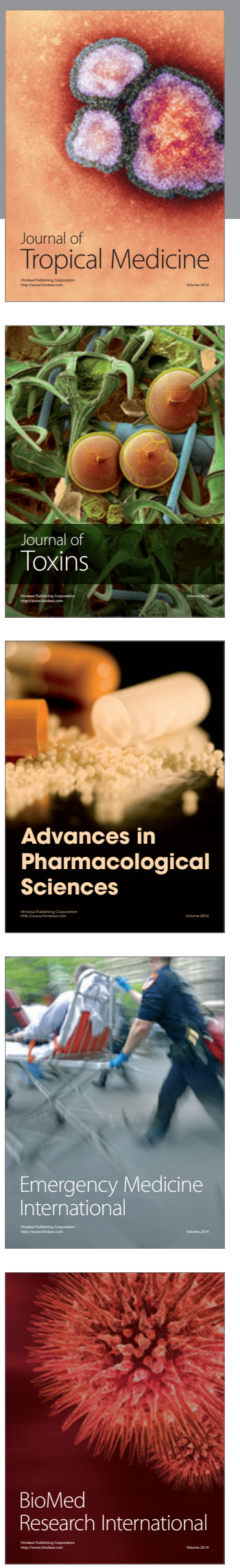
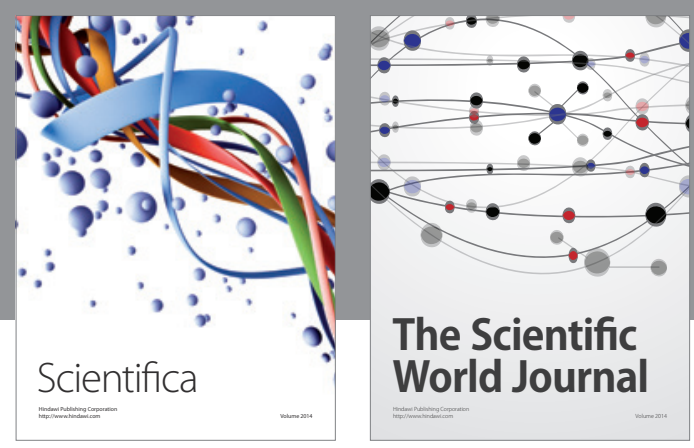

The Scientific World Journal
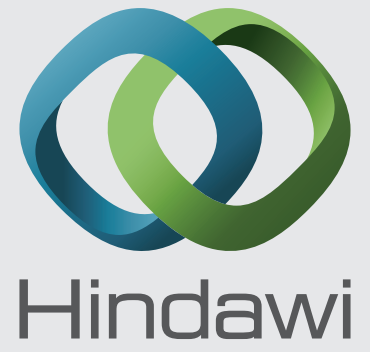

Submit your manuscripts at

http://www.hindawi.com
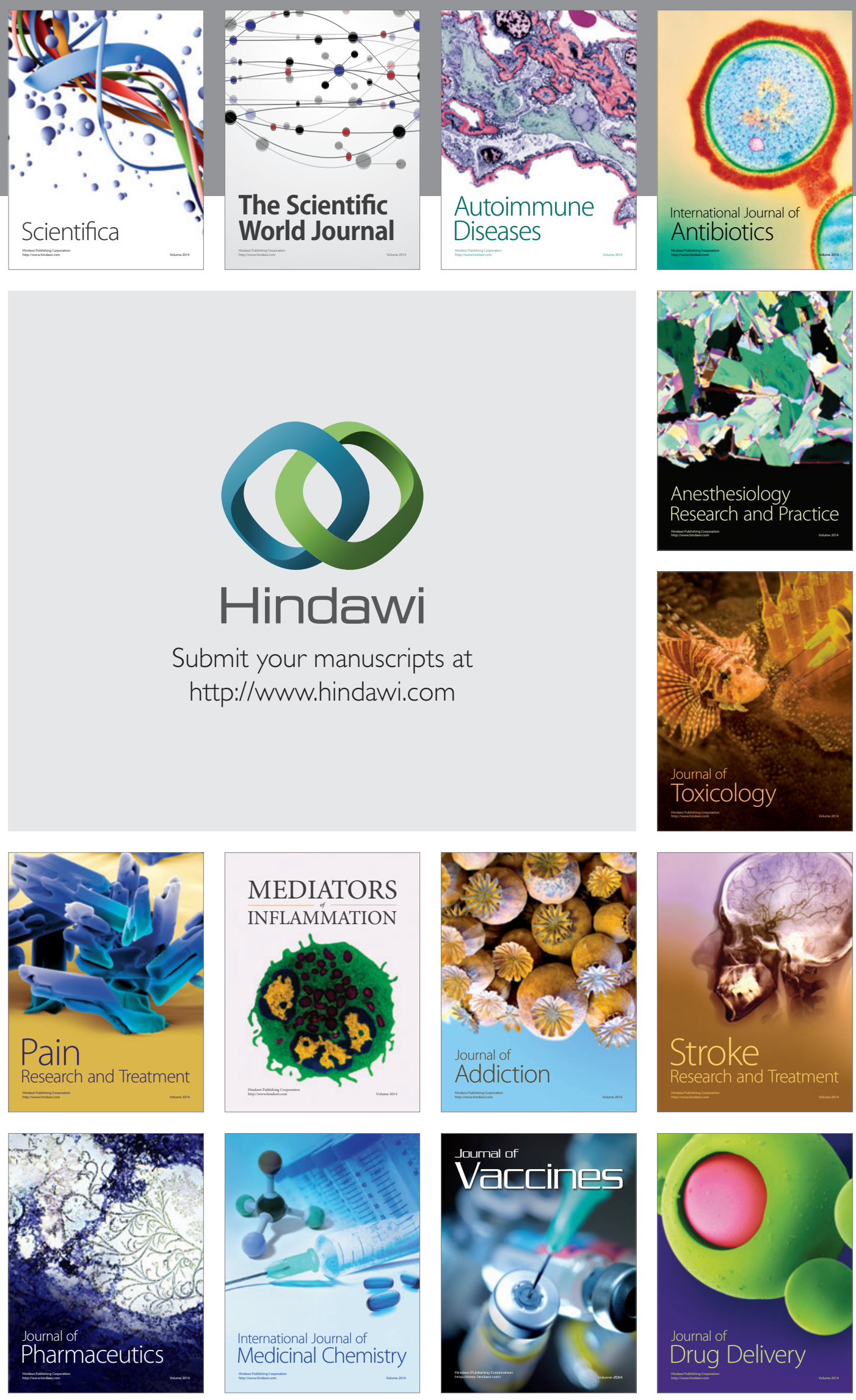